\title{
GROWTH AND MORTALITY OF RED LIONFISH, PTEROIS VOLITANS (ACTINOPTERYGII: SCORPAENIFORMES: SCORPAENIDAE), IN THE PARQUE NACIONAL ARRECIFE ALACRANES, SOUTHERN GULF OF MEXICO, AS DETERMINED BY SIZE-FREQUENCY ANALYSIS
}

\author{
Karla D. RODRÍGUEZ-CORTÉS ${ }^{1}$, Alfonso AGUILAR-PERERA ${ }^{1 *}$, \\ and José L. BONILLA-GÓMEZ ${ }^{2}$ \\ ${ }^{1}$ Departamento de Biología Marina, Universidad Autónoma de Yucatán, Mérida, Yucatán, México \\ ${ }^{2}$ Posgrado en Ciencias del Mar y Limnología, Universidad Nacional Autónoma de México, México, DF, México
}

Rodríguez-Cortés K.D., Aguilar-Perera A., Bonilla-Gómez J.L. 2015. Growth and mortality of red lionfish, Pterois volitans (Actinopterygii: Scorpaeniformes: Scorpaenidae), in the Parque Nacional Arrecife Alacranes, southern Gulf of Mexico, as determined by size-frequency analysis. Acta Ichthyol. Piscat. 45 (2): $175-179$.

Background. Biological invasions represent a threat to the ecological stability of the ecosystem. Two lionfish species, the red lionfish and the devil firefish — both tropical marine predators native to the Indo-Pacific — were introduced to the Atlantic Ocean. However, only one-the red lionfish, Pterois volitans (Linnaeus, 1758) - has reached the level of an invasive species so far. It is crucial to learn its biology and ecology to understand trends of its invasion and impacts on native fauna, and to determine ecological changes as the invasion progresses. This study reports the growth and mortality of $P$. volitans in coral reefs of the Parque Nacional Arrecife Alacranes, off the northern Yucatan Peninsula, Mexico, in Southern Gulf of Mexico.

Materials and methods. Lobster diver fishers participated in voluntary captures of lionfish during the lobster fishing seasons of 2010-2012. In the laboratory, lionfish were taxonomically identified, measured, and weighed. Their length-weight relation was determined according to the commonly used equation: $W=a \mathrm{TL}^{b}$. Fish total lengths were used to calculate the parameters of the von Bertalanffy growth function (VBGF) of lionfish based on the size-frequency analysis routine ELEFAN in the FiSAT II software.

Results. A total of 776 lionfish ( 9.0 to $38.9 \mathrm{~cm}$ in total length, 7 to $874 \mathrm{~g}$ in total wet weight) were collected. The VBGF parameters estimated were $L_{\infty}=42 \mathrm{~cm}, K=0.88^{-1}, t_{0}=-0.107$ years. The total mortality instantaneous rate $(Z)$ calculated by the total length converted catch curve was 2.06 year $^{-1}$.

Conclusion. This study provides first calculation of growth parameters and mortality of $P$. volitans in Southern Gulf of Mexico as determined by size-frequency analysis. Results contribute to the knowledge on the biology of $P$. volitans and to a better understanding of aspects of its biological invasion in the region.

Keywords: Alacranes Reef, Yucatan Peninsula, invasive species, marine fish, von Bertalanffy

\section{INTRODUCTION}

The red lionfish, Pterois volitans (Linnaeus, 1758), is an introduced species currently invading many coral reefs of the Western Atlantic (Schofield 2010, Côté et al. 2013). It is one of two lionfish introduced to the Atlantic Ocean (Hamner et al. 2007). The second species is the devil firefish, Pterois miles (Bennett, 1828). Both are tropical marine predators native to the Indo-Pacific. Only $P$. volitans, however, has reached the level of an invasive species so far (Whitfield et al. 2002) representing $93 \%$ of the invasive population in the region (Hamner et al. 2007). More than 30 years after its suspected accidental introduction off the eastern coast of the United States (Whitfield et al. 2002), the specimens of red lionfish, P. volitans, grow larger now and its populations are more dense compared to those in their native coral reefs in the Indo-Pacific Ocean (Darling et al. 2011).

The red lionfish invasion poses a threat to the coral reef biodiversity because of its fast population growth and increased predation rate on native fish may cause native fish population to decline (Green et al. 2012). Thus, it is crucial to obtain as much biological information as possible of $P$. volitans for better elucidating how it is impacting the invaded marine environment (Barbour et al. 2011).

In the Western Atlantic, Potts et al. (2011) estimated growth parameters of the red lionfish, based on sagittal 
otoliths of specimens from Onslow Bay, North Carolina, United States, using the von Bertalanffy growth function (VBGF):

$$
L_{t}=455.1 \mathrm{~mm}\left[1-e^{-0.32(t+1.22)}\right]
$$

and Barbour et al. (2011) did the same from the same area:

$$
L_{t}=425.2 \mathrm{~mm}\left[\left(1-e^{-0.47(t+0.05)}\right]\right.
$$

Recently in Cayman Islands, Edwards et al. (2014) calculated growth parameters using otoliths:

$$
L_{t}=349 \mathrm{~mm}\left[\left(1-e^{-0.42(t+1.01)}\right]\right.
$$

In the Southern Gulf of Mexico, the red lionfish was detected late in 2009 (Aguilar-Perera and Tuz-Sulub 2010) where it has invaded the Parque Nacional Arrecife Alacranes off the northern Yucatan Peninsula (LópezGómez et al. 2014). So far, relatively little is known on its biological aspects in this area. Consequently, the objective of this work was to estimate growth parameters, based on size-frequency analysis, and mortality of Pterois volitans from the Parque Nacional Arrecife Alacranes, Southern Gulf of Mexico.

\section{MATERIALS AND METHODS}

Study area. The Alacranes reef $\left(22^{\circ} 31^{\prime} 28 \mathrm{~N}, 89^{\circ} 42^{\prime} 44 \mathrm{~W}\right)$, the largest reef formation in Southern Gulf of Mexico, is located $135 \mathrm{~km}$ off the northern Yucatan Peninsula (Chávez et al. 2007). In 1994, due to its high biodiversity, the Alacranes reef was declared a natural protected area known as the Parque Nacional Arrecife Alacranes (PNAA). It must be emphasized, however, that the PNAA is a commercially important fishery zone for the spiny lobster (Panulirus argus) where three fishermen groups catch lobster from July to February each year (Rios-Lara et al. 2007).

Fieldwork and laboratory. Diver fishers collected lionfish using spear guns, from July 2010 to February 2012 at depths ranging from $5 \mathrm{~m}$ to $20 \mathrm{~m}$. Participant fishers received orientation briefings during specific workshops where they were invited to collect red lionfish, as much as possible, during their fishing journeys in the lobster fishing season (July to February) in the PNAA. Instructions given to fishers specified that the lionfish collected should be kept frozen in labelled bags and basic information from the collection site should be recorded (see López-Gómez et al. 2014 for details). There was no collection of lionfish during the lobster closed season (March-June). Specimens caught were preserved frozen, kept in labelled polyethylene bags, and transported to the laboratory of the Campus of Biological Sciences of the Universidad Autónoma de Yucatán. At the laboratory, the specimens collected were taxonomically identified to species according to Schultz (1986), measured in total length [cm], and wet weighed [g]. It was not possible to determine the sex of specimens at the time of processing, so total length data of all specimens were pooled for the analyses.
Data analysis. Based on log-converted total weight and total length, the parameters $a$ and $b$ of the length-weight regression analysis were calculated according to the equation:

$$
\ln W=\ln (a)+\ln (b) \mathrm{TL}
$$

and expressed as

$$
W=a \mathrm{TL}^{b}
$$

Parameter $b$ is the exponent of the arithmetic form of the length-weight relation and the slope of the regression line in the logarithmic form, while parameter $a$ is the coefficient of the arithmetic length-weight relation and the intercept of the logarithmic form (Froese 2006). When $b>3$ (positive allometric growth), large fish increased in height or width more than in length since large fish in the sample are thicker than small fish. By contrast, when $b<3$ (negative allometric growth) large fish change their body shape to become more elongated or small specimens were in better nutritional condition at the time of sampling. When $b=3$ (isometric growth), small fish in the sample have the same form and condition as large specimens (Froese 2006). The $95 \%$ confidence intervals for the parameter $b$ (CI 95\%) were calculated to determine if the hypothetical value of isometric growth $(b=3)$ fell between these intervals (Froese 2006).

Parameters of the von Bertalanffy growth function (VBGF) were calculated, based on lionfish length frequency distributions (class intervals of $2 \mathrm{~cm}$ in total length), using the ELEFAN routine of the software Fish Fisheries Stock Assessment Tools (FiSAT II) (Gayanilo et al. 1997). The VBGF is expressed as:

$$
L_{t}=L_{\infty}\left[1-e^{-k(t-t 0)}\right]
$$

where $L_{t}$ is the length at age $t, L_{\infty}$ is asymptotic length, $K$ is the growth rate (year-1), and $t_{0}$ is the hypothetical age of fish at zero length. For assessing the variability of $K$ and taking into account the uncertainty in the estimation of asymptotic length, estimated values of maximum length and its $95 \%$ confidence interval from the routine Maximum Length Estimation included in FiSAT II (Gayanilo et al. 1997) were used to obtain a range of possible values of $K$.

The instantaneous rate of total mortality $(Z)$ was determined by the length converted catch curve which, in the absence of declared exploitation of lionfish in the PNAA, is equivalent to the instantaneous rate of natural mortality $(M)$. Also, an independent estimate of $M$ was performed using the empirical equation of Pauly (1983). The alternative to calculate this latter estimate is available in the FiSAT II package and is a commonly used indirect method of estimating natural mortality related to VBGP and mean environmental temperature $T\left[{ }^{\circ} \mathrm{C}\right]$. This method assumes a relation between fish size and natural mortality. While the relation is relatively weak, the inclusion of mean environmental temperature increases the fit since fish in warmer waters tend to have higher mortality rates compared to those in cooler waters (Pauly 1983). 


\section{RESULTS}

Over the study period, 776 red lionfish were collected. Fish ranged from 9.0 to $38.9 \mathrm{~cm}$ in total length (TL) and from 7 to $874 \mathrm{~g}$ in total wet weight $(W)$. Maximum length $(38.9 \mathrm{~cm} \mathrm{TL})$ and maximum wet weight $(874 \mathrm{~g})$ were recorded in October 2012 and the smallest length ( $9 \mathrm{~cm} \mathrm{TL})$ and the smallest weight ( $7 \mathrm{~g}$ ) in August 2010 (Fig. 1). Wet weights were related to total lengths $\left(r^{2}=0.97\right.$; Table 1$)$ according to the formula:

$$
W=0.011 \cdot \mathrm{TL}^{3.33}
$$

The parameter $b$ (3.33) in the combined length-weight relation was significantly different from the isometric value of growth $(t$-student $=-1.3606, n=776 ; P>0.05)($ Table 1).

Table 1

Descriptive statistics and estimated length-weight relation parameters of red lionfish, Pterois volitans, in the Parque Nacional Arrecife Alacranes, off the northern Yucatan Peninsula (July 2010-February 2012)

\begin{tabular}{|c|c|}
\hline Parameter & Value \\
\hline$n$ & 776 \\
\hline Total length $[\mathrm{cm}]$ & $9.0-38.9$ \\
\hline Total weight [g] & $7-874$ \\
\hline$a$ & 0.011 \\
\hline.$\frac{0}{\infty}$ & 3.33 \\
\hline $\mathrm{SE}(b)$ & 0.017 \\
\hline CI 95\% (b) & $3.30-3.37$ \\
\hline$r^{2}$ & 0.97 \\
\hline
\end{tabular}

$n=$ number of specimens in the analysis; Regression parameters: $a$, scaling constant; $b$, slope; $\mathrm{CI}$, confidence interval; SE, standard error; $r^{2}$ coefficient of determination.
The calculated VBGF based on observed TL at age was:

$$
L_{t}=42 \mathrm{~cm}\left[1-e^{-0.88(t-0.107)}\right]
$$

The total mortality instantaneous rate $(Z)$ calculated by the total length converted catch curve was 2.06 year $^{-1}(1.22$ $-2.90 ; 95 \%$ confidence interval). In the PNAA at least two cohorts were identified from the curves since 2010 through 2012 (Fig. 1), with the highest frequency of adult sizes detected in October 2012. The instantaneous rate of natural mortality $(M)$ was 1.46 year $^{-1}$ in relation to the average temperature of the sampling period in the $\operatorname{PNAA}\left(26.7^{\circ} \mathrm{C}\right)$.

\section{DISCUSSION}

This study is the first report of growth parameters of red lionfish, Pterois volitans, in Southern Gulf of Mexico as determined by size-frequency analysis. Growth parameters calculated before of specimens from North Carolina (Barbour et al. 2011, Potts et al. 2011) and Cayman Islands (Edwards et al. 2014) were based on readings of sagittal otoliths. The maximum size $(39 \mathrm{~cm} \mathrm{TL})$ of $P$. volitans detected in this work is the largest ever recorded in the PNAA, and similar to that detected in a specimen from Cayo Arenas - a site located approximately $50 \mathrm{~km}$ to the east from the PNAA (Aguilar-Perera et al. 2013). This maximum size ( $39 \mathrm{~cm} \mathrm{TL})$ of $P$. volitans is the largest ever recorded in Southern Gulf of Mexico too. However, the maximum size of $P$. volitans ever recorded in the invaded Western Atlantic was $46.4 \mathrm{~cm}$ TL of a specimen taken off North Carolina (Potts et al. 2011).

The calculated $b$ parameter (3.33) in the lengthweight relation indicated a positive allometric growth of $P$. voltians in the PNAA. However, a previous estimation $(b=3.30)$ from the same area shown isometric growth ( $n=455$ lionfish) (Perera-Chan and Aguilar-Perera 2014).
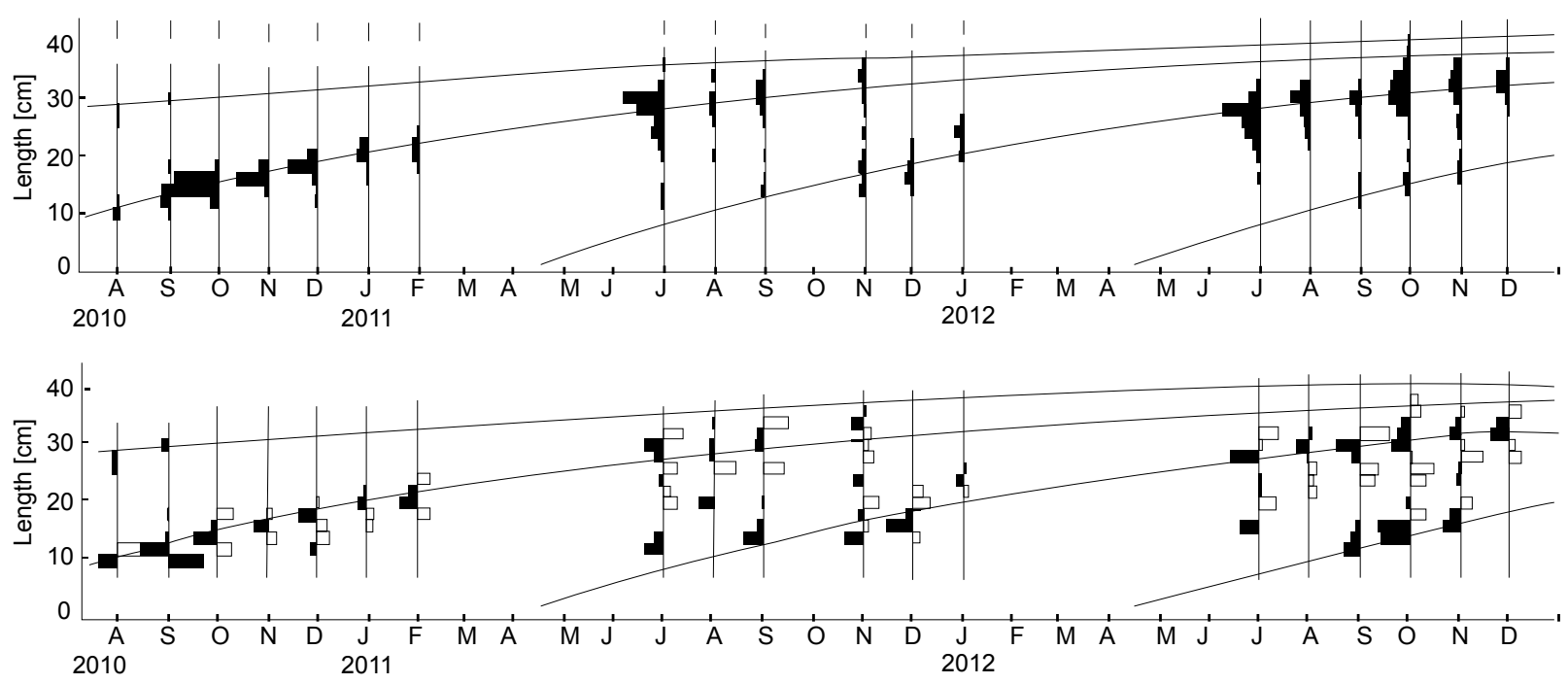

Fig. 1. Monthly growth curve variation of red lionfish, Pterois volitans, calculated through the ELEFAN-I model in FiiSAT II based on length frequency data (above) and restructured length frequency data (below), from the Parque Nacional Arrecife Alacranes, off the northern Yucatan Peninsula, Mexico; Data was available only in the period JulyFebruary each year which corresponds to the lobster fishing season in the area 
Parameter $b$ can differ in Pterois volitans from other geographic areas, such as North Carolina where this value reached 2.89 (Barbour et al. 2011). In the Cayman Islands it amounted to 3.24 (Edwards et al. 2014) and in the Bahamas it was 3.29 (Green et al. 2011). In general, parameter $b$ is subject to changes because of sample size, environmental factors, and seasonality (Froese 2006).

The VBGF parameters of lionfish in the PNAA showed similarities and differences with growth parameters of Pterois volitans from other areas in the Western Atlantic region. Barbour et al. (2011) calculated a value of $L_{\infty}=42$ $\mathrm{cm}$ for the lionfish and Potts et al. (2011) of $L_{\infty}=45 \mathrm{~cm}$; both of them off the North Carolina coast (USA). This parameter was relatively similar to that of the PNAA $\left(L_{\infty}=\right.$ $42.5 \mathrm{~cm})$ but higher than that calculated $\left(L_{\infty}=34.9 \mathrm{~cm}\right)$ in the Cayman Islands (Edwards et al. 2014). Lionfish from the PNAA appeared to reach their maximum length faster than fish from the Cayman Islands and North Carolina, with $K$ values for fish from the PNAA equal to 0.88 and $K$ values for lionfish from North Carolina equal 0.32 (Potts et al. 2011) and 0.47 (Barbour et al. 2011) and Cayman Islands equal to 0.42 (Edwards et al. 2014). In general, in comparison to growth rate values for other tropical fish $(K$ $=0.1$ to 0.3 ), the lionfish appears to reach their asymptotic maximum length faster (Edwards et al. 2014). Estimates of lionfish's growth parameters in the PNAA may have been affected since there is a lack of older and larger lionfish (since the recent establishment of lionfish in the area) which may produce a truncated growth curve.

Estimates of natural- (1.46 year $\left.^{-1}\right)$ and total mortality (2.06 year $^{-1}$ ) of red lionfish from the PNAA are the first estimates in the Southern Gulf of Mexico. Estimates of total mortality by the length converted catch curve (Pauly 1983) can be considered equivalent to the natural mortality rate $(Z=M)$ in the absence of formal fishing practices in the area. In the particular case of the PNAA, however, special considerations have to be taken with this calculation because a removal of more than 700 lionfish in 18 months may indicate that fishing mortality could be high. The natural mortality calculated $(M)$ for lionfish in the PNAA (1.46 year $\left.{ }^{-1}\right)$ is very high compared to value of $M$ for a typical of short-lived fish which it could be ranged from 0.2 to 0.5 (Froese and Pauly 2014). This inferred value of $M$ has previously been used for modelling growth in lionfish (Barbour et al. 2011). Consequently, we suggest caution with this calculated value for $M$ for lionfish in the Southern Gulf of Mexico.

We recommend using sagittal otoliths to calculate growth parameters of lionfish in the area, and then make comparisons with the growth parameters calculated in this work in the PNAA. We also recommend conducting studies to evaluate the impact the removals may have on the lionfish population by comparing possible changes in lionfish growth between removed and non-removed areas within the PNAA.

\section{ACKNOWLEDGEMENTS}

We thank Rene Kantun, Yrvin Ramírez, and Axcan Moreno, personnel of the Parque Nacional Arrecife
Alacranes (PNAA), who provided logistic support. We also acknowledge many lobster fishers who caught lionfish specimens. We thank Armin Tuz-Sulub, Leidy Perera-Chan, Luis Quijano-Puerto, and María José López-Gómez, who helped in many ways during previous phases of this study.

\section{REFERENCES}

Aguilar-Perera A., Perera-Chan L., Quijano-Puerto L. 2013. Record body size for the red lionfish, Pterois volitans (Scorpaeniformes), in the Southern Gulf of Mexico. Gulf Caribbean Research 25 (1):121-123.

Aguilar-Perera A., Tuz-Sulub A. 2010. Non-native, invasive red lionfish (Pterois volitans [Linnaeus, 1758]: Scorpaenidae]), is first recorded in the southern Gulf of Mexico, off the northern Yucatan Peninsula, Mexico. Aquatic Invasions 5 (Suppl. 1): S9-S12.

DOI: 10.3391/ai.2010.5.S1.003

Barbour A.B., Allen M.S., Frazer T.K., Sherman K.D. 2011. Evaluating the potential efficacy of invasive lionfish (Pterois volitans) removals. PLoS ONE 6 (5): e19666.

DOI: 10.1371/journal.pone.0019666

Chávez E., Tunnell J.W., Withers K. 2007. Reef zonation and ecology: Veracruz shelf and Campeche Bank. Pp. 41-67. In: Tunnell J.W., Chávez E.A. Whiters K. (eds.) Coral reefs of the southern Gulf of Mexico. Texas A\&M Press, College Station, TX, USA.

Côté I.M., Green S.J., Hixon M.A. 2013. Predatory fish invaders: Insights from Indo-Pacific lionfish in the western Atlantic and Caribbean. Biological Conservation 164: 50-61.

DOI: $10.1016 /$ j.biocon.2013.04.014

Darling E.S., Green S.J., O’Leary J.K., Côté I.M. 2011. Indo-Pacific lionfish are larger and more abundant on invaded reefs: A comparison of Kenyan and Bahamian lionfish populations. Biological Invasions 13 (9): 2045-2051.

DOI: $10.1007 / \mathrm{s} 10530-011-0020-0$

Edwards M.A., Frazer T.K., Jacoby C.A. 2014. Age and growth of invasive lionfish (Pterois spp.) in the Caribbean Sea, with implications for management. Bulletin of Marine Science 90 (4): 953-966.

DOI: $10.5343 / \mathrm{bms} .2014 .1022$

Froese R. 2006. Cube law, condition factor and weightlength relationships: History, meta-analysis and recommendations. Journal of Applied Ichthyology 22 (4): 241-253. DOI: $10.1111 /$ j.1439-0426.2006.00805.x

Froese R., Pauly D. (eds.) 2014. FishBase. [version 06/2014] http://www.fishbase.org

Gayanilo F.C.jr., Sparre P., Pauly D. 1997. The FAOICLARM stock assessment tools (FiSAT). FAO Computerized Information Series (Fisheries). No. 8. FAO, Rome, Italy.

Green S.J., Akins J.L., Côté I.M. 2011. Foraging behaviour and prey consumption in the Indo-Pacific lionfish on Bahamian coral reefs. Marine Ecology Progress Series 433: 159-167. DOI: $10.3354 / \operatorname{meps} 09208$ 
Green S.J., Akins J.L., Maljković A., Côté I.M. 2012. Invasive lionfish drive Atlantic coral reef fish declines. PLoS ONE 7 (3): e32596.

DOI: 10.1371/journal.pone.0032596

Hamner R.M., Freshwater D.W., Whitfield P.E. 2007. Mitochondrial cytochrome $b$ analysis reveals two invasive lionfish species with strong founder effects in the western Atlantic. Journal of Fish Biology 71 (Suppl. B): 214-222.

DOI: $10.1111 / \mathrm{j} .1095-8649.2007 .01575 . x$

López-Gómez M.J., Aguilar-Perera A., Perera-Chan L. 2014. Mayan diver-fishers as citizen scientists: Detection and monitoring of the invasive red lionfish in the Parque Nacional Arrecife Alacranes, southern Gulf of Mexico. Biological Invasions 16 (7): 1351-1357. DOI: $10.1007 / \mathrm{s} 10530-013-0582-0$

Pauly D. 1983. Some simple methods for the assessment of tropical fish stocks. FAO Fisheries Technical Paper No. 234. FAO, Rome, Italy.

Perera-Chan L., Aguilar-Perera A. 2014. Lengthweight and length-length relationships of the invasive red lionfish [Pterois volitans (Linnaeus, 1758): Scorpaenidae] in the Parque Nacional Arrecife Alacranes, Southern Gulf of Mexico. Journal of Applied Ichthyology 30 (1): 202-203.

DOI: $10.1111 /$ jai.12294
Potts J.C., Berrane D., Morris J.A.jr. 2011. Age and growth of lionfish from the western North Atlantic. Proceedings of the Gulf Caribbean Fisheries Institute No. 63: 1 .

Rios-Lara V., Salas S., Bello-Pineda J., Peniche-Ayora I. 2007. Distribution patterns of spiny lobster (Panulirus argus) at Alacranes reef, Yucatan: Spatial analysis and inference of preferential habitat. Fisheries Research 87 (1): 35-45.

DOI: 10.1016/j.fishres.2007.06.021

Schofield P.J. 2010. Update on geographic spread of invasive lionfishes (Pterois volitans [Linnaeus, 1758] and P. miles [Bennett, 1828]) in the western North Atlantic Ocean, Caribbean Sea and Gulf of Mexico. Aquatic Invasions 5 (Suppl. 1): S117-S122. DOI: $10.3391 /$ ai.2010.5.S1.024

Schultz E.T. 1986. Pterois volitans and Pterois miles: two valid species. Copeia 1986 (3): 686-690. DOI: $10.2307 / 1444950$

Whitfield P., Gardner T., Vives S.P., Gilligan M.R., Courtenay W.R., Carleton R., Hare J.A. 2002. Biological invasions of the Indo-Pacific lionfish Pterois volitans along the Atlantic coast of North America. Marine Ecology Progress Series 235: 289-297. DOI: $10.3354 /$ meps 235289

Received: 3 July 2014 Accepted: 25 January 2015 Published electronically: 30 June 2015 